\title{
Low-pressure drip system in reduced tillage cotton
}

\author{
B. Marsh ${ }^{1}$, M. Dowgert ${ }^{2}$, R. Hutmacher ${ }^{1} \&$ C. Phene ${ }^{3}$ \\ ${ }^{1}$ University of California Shafter Research and Extension Center, \\ Shafter, CA, USA \\ ${ }^{2}$ Netafim, USA, Fresno, CA, USA \\ ${ }^{3} \mathrm{SDI}+$, Fresno, CA, USA
}

\begin{abstract}
Research has shown the soil and water conservation advantages of subsurface drip irrigation. Low-pressure drip system (LPS) technology has shown a high potential for economically improving application efficiency of irrigation systems under sandy soil conditions in areas where water is scarce and/or expensive. Energy costs are reduced as less than 70 grams per square $\mathrm{cm}$ is needed for system operation. The low-pressure system is installed just below the soil surface, it operates at very low flow and pressure, and it can stay on for longer periods of time without generating runoff or deep percolation. This study is designed to assess LPS under a reduced tillage system without the use of any other irrigation method for stand establishment. This combines the benefits of increased water use efficiency and lower energy costs for improved irrigation efficiency and fewer tillage operations resulting in lower production costs and less airborne dust. Since the drip tape was installed two years ago, only 3 cultivation passes have been made. No major tillage operations, the kind that generate lots of dust, have been performed. LPS water usage was $15 \%$ less than furrow irrigation and yields of cotton (Gossypium hirsutum) and blackeye beans (Vigna unguiculata) were comparable to yields from furrow irrigation. This system does present some challenges in stand establishment on very sandy soils and with weed control, which continue to be investigated. Herbicides requiring incorporation were not used. Weeds can be controlled in cotton using glyphosate and other herbicides. Fewer chemical weed control options are available for blackeye beans. The LPS technology has many potential technical, energy and economic advantages over standard drip and subsurface drip irrigation.
\end{abstract}

Keywords: cotton, low-pressure drip irrigation. 


\section{Introduction}

Recently, water, energy, fertilizer, pesticides, labor cost and the capital investment in modern irrigation systems have risen dramatically and at a rate greater than farmer returns. Studies have demonstrated that drip irrigation can improve water use efficiency, reduce fertilizer losses and reduce application of pesticides and fungicides, particularly when compared with flood, furrow and sprinkler irrigation [1-7]. As drip irrigation knowledge has evolved, Netafim Irrigation has developed Low Pressure Systems (LPS) that operate at 70 grams per square $\mathrm{cm}$ pressure while achieving a distribution uniformity of $90 \%$ or better. The conversion of leveled furrow irrigated fields to LPS using pressurized district water eliminates additional energy expenditures. It also conserves significant water and energy and allows the use of low-pressure components, thus reducing the capital inputs of LPS. Soil moisture wetting patterns and resultant rooting patterns are affected by drip irrigation frequency and amount of water applied [8].

The objective of this project was to evaluate the use of LPS drip in a reduced tillage cotton system with the shallow buried tape remaining intact for three years with no other irrigation method used to germinate the seed. Research results will be used to validate LPS irrigation design and management, and to demonstrate on-farm water, energy, chemigation, and labor savings in a reduced till system.

\section{Materials and methods}

This project consists of two low-pressure irrigation treatments on undisturbed seedbeds replicated four times in a randomized block design. The drip system operates at 70 grams per square $\mathrm{cm}$. Each system delivers approximately an equal amount of water on an area basis. The treatments are LPS-200: 2 drip lines on $200 \mathrm{~cm}$ beds $(75 \mathrm{~cm}$ lateral spacing, $60 \mathrm{~cm}$ emitter spacing, $100 \mathrm{~cm}$ row spacing) and LPS-150: 1 drip line on $150 \mathrm{~cm}$ beds (45 cm emitter spacing, $75 \mathrm{~cm}$ row spacing). The row spacing represents typical bed configuration for multiple rotation crops.

Drip lines were installed $10 \mathrm{~cm}$ below the soil surface in the spring of 2005 . Bed shaping in the early spring and planting have been the only tillage operations since the tape was installed. Each plot was 8 beds wide by $100 \mathrm{~m}$. The plots were on a Wasco sandy loam (coarse-loamy, mixed, nonacid, thermic Typic Torriorthent) soil.

Cotton (Gossypium hirsutum) was grown in 2005 and blackeye bean (Vigna unguiculata) was grown in 2006. N-P-K fertilizers were added to meet the crop requirement and were injected in the irrigation water as needed to maintain optimal petiole tissue levels (measured weekly). Acid (N-pHURIC, 10/55) was injected in all LPS irrigation water to maintain the solution $\mathrm{pH}$ at $6.5+/-0.04$. Plots were mechanically harvested.

Soil moisture sensors were installed at 15, 40 and $60 \mathrm{~cm}$ deep in one row of each treatment. In-season irrigation was determined by calculating crop 
evapotranspiration (ETc), using on-site CIMIS weather station measurements (ETo) and a generic crop coefficient for this area $(\mathrm{Kc})$, where ETc $=$ ETo $\mathrm{x} \mathrm{Kc}$. Feedback from the rate of change of soil moisture measurements was used to adjust irrigation schedules.

Uniformity testing was conducted on a single row in each replication. Emitter output was measured every $10 \mathrm{~m}$ down the row. A hole is dug deep enough to uncover the drip tape and place a small cup under the emitter to collect water. The drip tape was cleaned off and a piece of black electrical tape was wrapped around the drip tape about $3 \mathrm{~cm}$ from each side of the emitter. The tape prevents water from travelling down the drip tube. A small cup is placed underneath the emitter to collect water for fifteen minutes. The water collected is measured in a $100-\mathrm{mL}$ graduated cylinder and recorded.

Soil and root samples were collected in a grid pattern from each plot. A $4 \mathrm{~cm}$ diameter tube was driven $3 \mathrm{~cm}$ deep into the wall of a pit and extracted. Soil samples were weighed and dried for moisture content. Root samples were washed free of soil and measured for length.

\section{Results}

Emitter uniformity across the field was very good exceeding $90 \%$ combined over years, see Figure 1. In 2005 uniformity was $94 \%$, however it dropped to just less than $10 \%$ in 2006 . System water pressure was less in 2006, at 55 grams per square $\mathrm{cm}$. This was due to filtration problems and was lower than desirable for optimum system operation although emitter uniformity was still very good. Multiple field and laboratory studies show similar results in tape that was either unused or having been buried for up to eight years [9-11]. It is predicted that the system could remain in place for extended years without a reduction in performance.

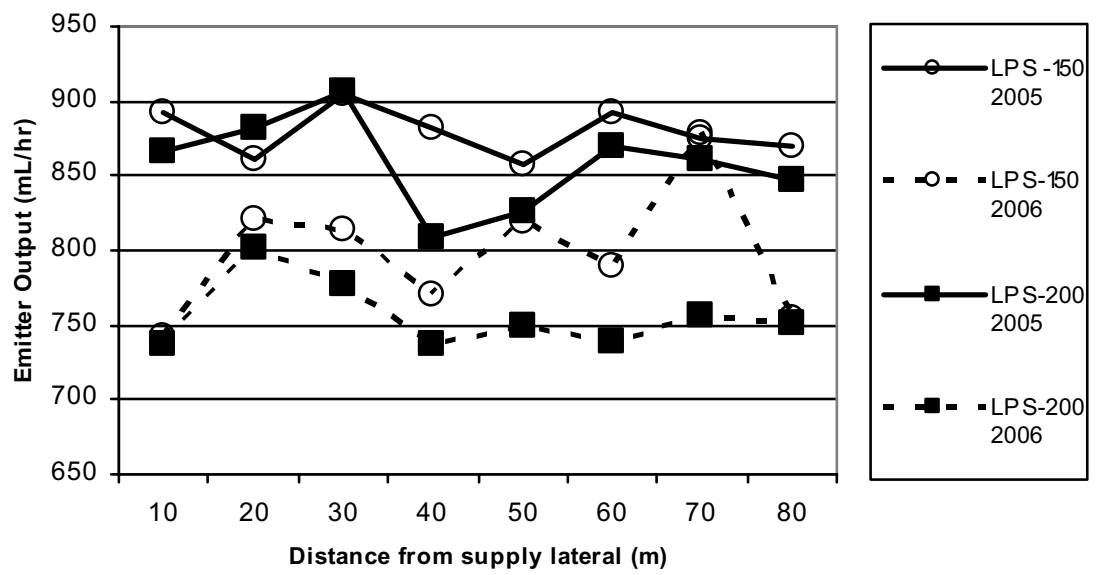

Figure 1: $\quad$ Emitter output. 
Control of irrigation water was easily accomplished using a combination of predicted ET, a changing crop coefficient according to plant growth stage and soil moisture feedback. To accomplish the objective of not using any other irrigation method to germinate the seed, the soil was well wetted prior to planting, see Figure 2. Tops of the bed were removed to plant into moisture. Plant population was not significantly different between the treatments and was within the acceptable range for the Southern San Joaquin Valley [12]. Soil moisture was allowed to dry down following planting and as the plants developed through mid-May with only one irrigation needed in early May. Irrigation duration increased and thus soil moisture also increased in mid to late May to stimulate plant growth. Irrigation management then utilized deficit water status reducing soil moisture from mid June to August to control vegetative plant growth before increasing soil moisture during the critical period of boll development. There was not an excess delivery of water as moisture readings at $60 \mathrm{~cm}$ remained fairly constant. Root growth and water uptake was minimal at that depth.

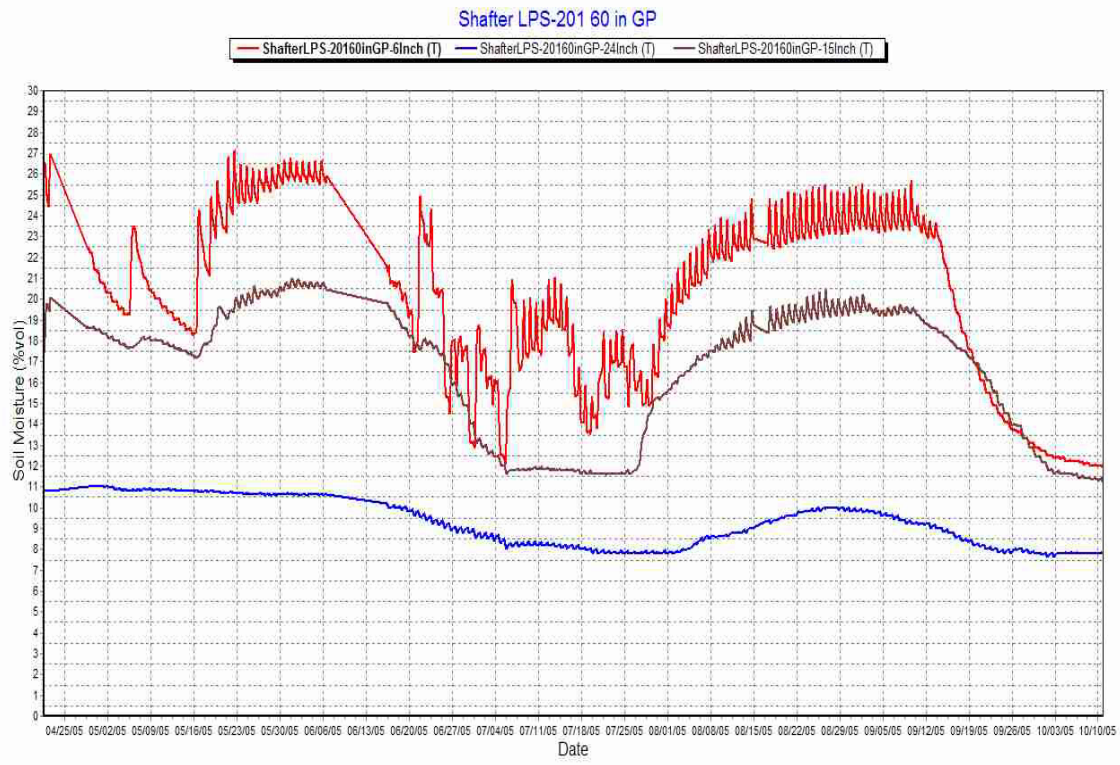

Figure 2: $\quad$ Soil moisture, LPS-150.

Plants became infected with fusarium wilt (Fusarium oxysporum) which had a limiting effect on plant growth and yield. The amount of water delivered was appropriate for the size of plants in the field. Water delivered generally remained directly below the drip lines and did not move below $50 \mathrm{~cm}$ deep. There was very little lateral water movement from the drip lines. As approximately equal amounts of water were delivered in each treatment, soil moisture around the single drip line was about twice the level of soil moisture around the two drip lines. In either case sufficient moisture was available for the desired growth pattern for cotton and blackeye beans. 


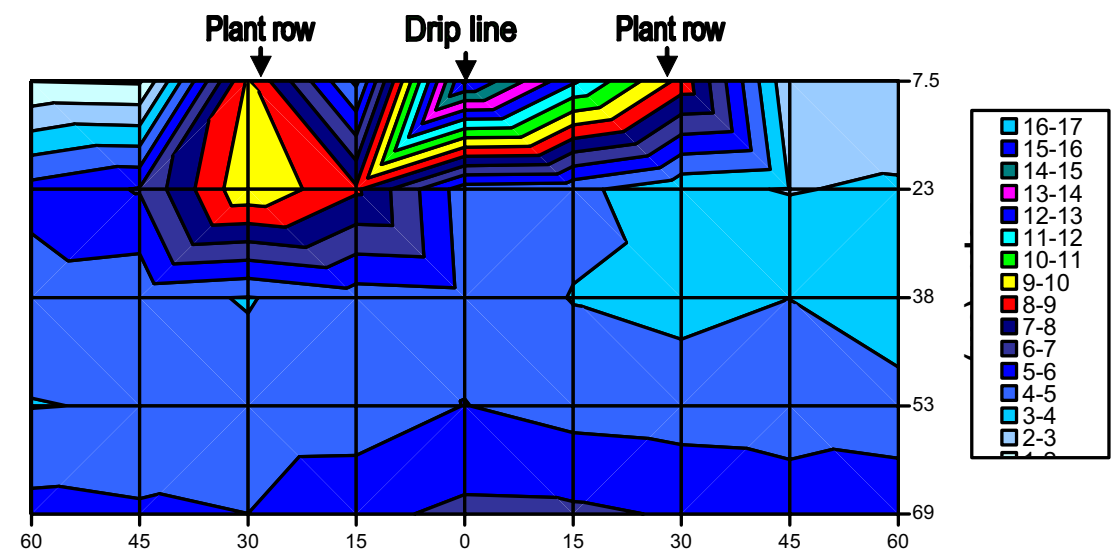

Horizontal Distance $(\mathrm{cm})$

Figure 3: $\quad$ Soil moisture content, LPS-150.

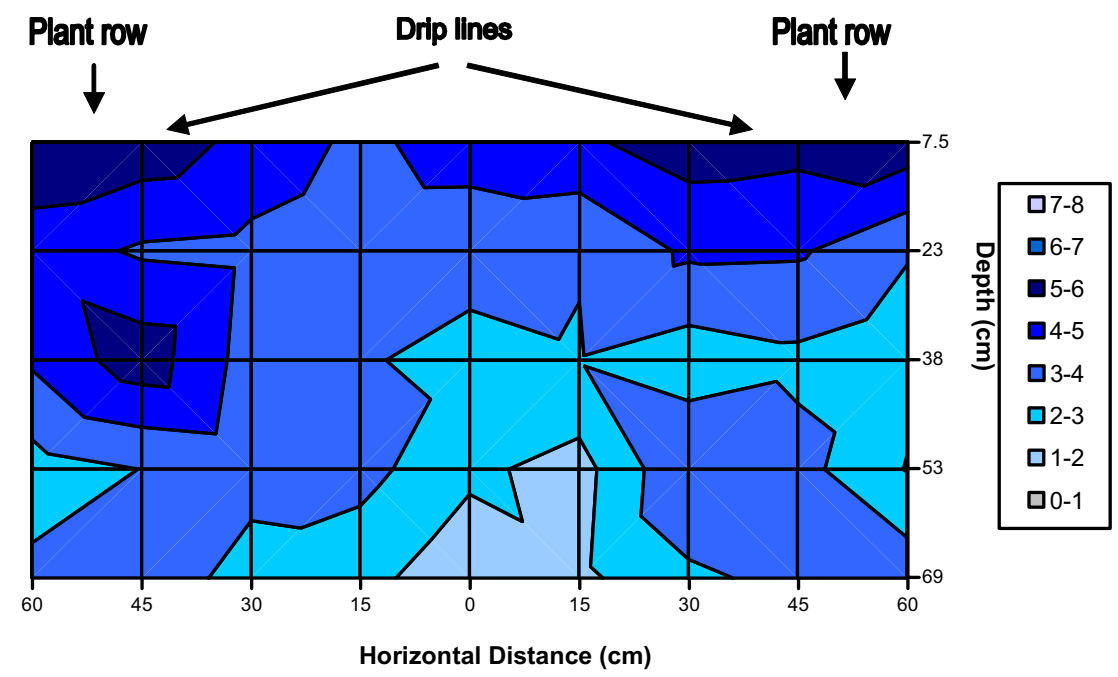

Figure 4: $\quad$ Soil moisture content, LPS-200.

Root growth responded to where soil moisture was and was generally confined to the upper $40 \mathrm{~cm}$. In the LPS-200 treatment, where the drip lines are $10 \mathrm{~cm}$ from the plant row, roots grew only in that area. In the LPS-150 treatment, where only one drip line is placed between the rows, root length density was greater toward the drip line than at depth directly below the plant row. Root length density within the wetted zones was sufficient for uptake of all 
available water which was ample for desired crop growth. It exceeded the 0.3 to $1.0 \mathrm{~cm} \mathrm{~cm}^{-3}$ requirement put forward by van Noordwijk [13]. However with the limited area of water availability and root exploration, supplemental fertilization was required. Cotton and blackeye bean yields were not significantly different between the treatments and similar to furrow irrigated yields.

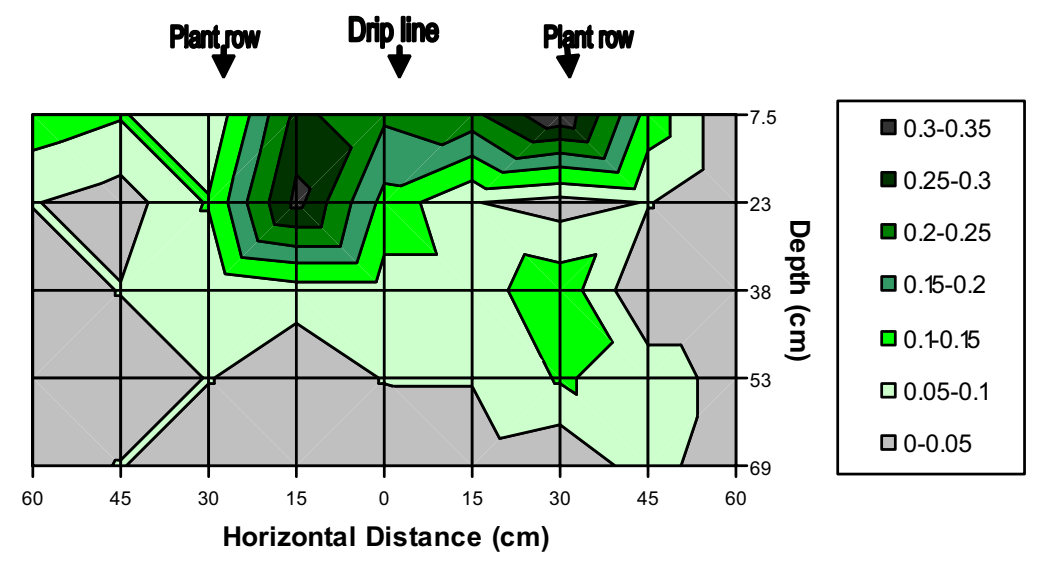

Figure 5: $\quad$ Root length density, LPS-150.

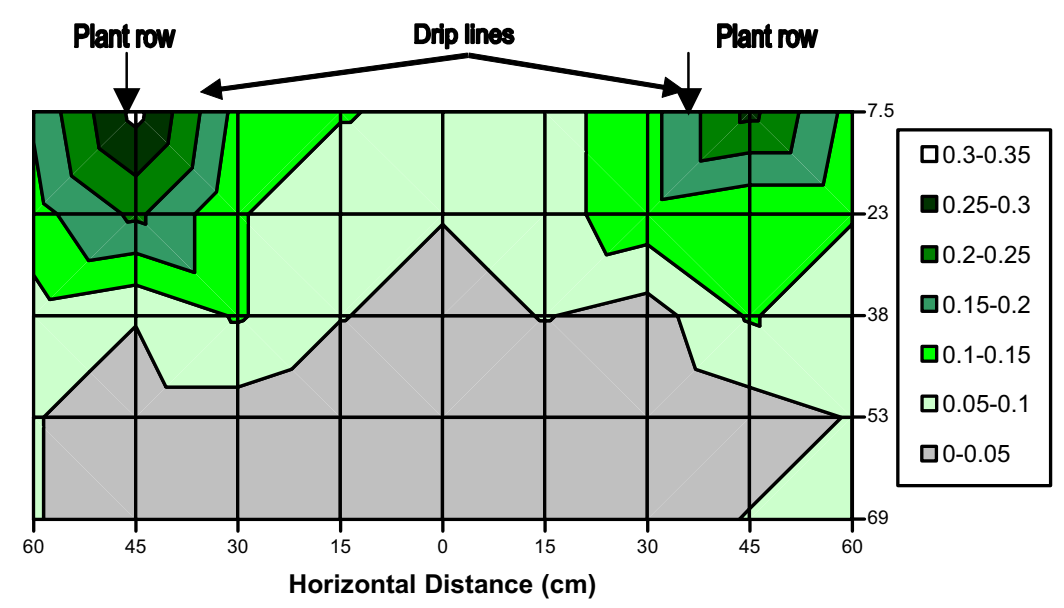

Figure 6: Root length density, LPS-200. 
Table 1: $\quad$ Agronomic responses to drip tape configuration.

\begin{tabular}{|c|c|c|c|}
\hline Treatment & $\begin{array}{c}2005 \\
\text { Cotton Lint Yield } \\
\left(\mathrm{kg} \mathrm{ha}^{-1}\right)\end{array}$ & $\begin{array}{c}\text { Plant Population } \\
\left(\# \mathrm{ha}^{-1}\right)\end{array}$ & $\begin{array}{l}\text { Applied Water } \\
(\mathrm{cm})\end{array}$ \\
\hline LPS 200 & 940 & 115,000 & 58.9 \\
\hline \multirow[t]{3}{*}{ LPS 150} & 1080 & 110,000 & 60.7 \\
\hline & ns & ns & \\
\hline & $\begin{array}{c}2006 \\
\text { Blackeye Bean Yield } \\
\left(\mathrm{kg} \mathrm{ha}^{-1}\right)\end{array}$ & $\begin{array}{l}\text { Plant Population } \\
\left(\# \mathrm{ha}^{-1}\right)\end{array}$ & $\begin{array}{l}\text { Applied Water } \\
(\mathrm{cm})\end{array}$ \\
\hline LPS 200 & 2576 & 147,200 & 69.6 \\
\hline \multirow[t]{2}{*}{ LPS 150} & 2601 & 148,100 & 72.1 \\
\hline & ns & ns & $\mathrm{ns}$ \\
\hline
\end{tabular}

\section{Conclusions}

The combination of a low pressure drip system and reduced tillage was effective in reducing water usage, energy requirements and fugitive dust while maintaining comparable yields with furrow irrigation. Extra attention to irrigation management, to sufficiently wet the soil where seeds were to be placed, and removing the tops of the bed were required for good seed germination. This was an issue with this project because of the limited lateral movement of water in the sandy soil. The drip system had good water delivery uniformity throughout the field. The durability of the drip tape will allow it to remain in place for several years. This irrigation system provides water, energy, chemigation, and labor savings in a reduced till system.

\section{References}

[1] Bucks, D.A., L.J. Erie, and O.F. French. Quantity and frequency of trickle and furrow irrigation for efficient cabbage production. Agronomy Journal 66:53-57, 1974.

[2] Camp, C.R., Thomas, W. M., and Green, C. C., Micro irrigation scheduling and tube placement for cotton in the southeastern coastal plain. Transactions of the ASAE 36:1073-1078, 1993.

[3] Hanson, B.R., Schwanki, L. J., Schulbach, K. F. and Pettygrove, G. S., A comparison of furrow, surface drip, and subsurface drip irrigation on lettuce yield and applied water. Agricultural Water Management 33:139157.

[4] Hodgson, A. S., Constable, G. A., Duddy, G. R., and Daniels, I. G., A comparison of drip and furrow irrigated cotton on a cracking clay soil. Water use efficiency, waterlogging, root distribution and soil structure. Irrigation Science 11:143-148, 1997. 
[5] Lamm, M. C., Davidson Jr., J. I., and Pitts D. J., Revision of EP-458: field evaluation of microirrigation systems. ASAE Paper No. 972. St. Joseph, Mich. 1997.

[6] Ottis, B., Henggeler, C. and Vories, E., Low-pressure, Drip-irrigation for Rice. American Society of Agronomy, 2006.

[7] Sammis, T. Comparison of sprinkler, trickle, subsurface and furrow irrigation methods for row crops. Agronomy Journal 72:701-704, 1980.

[8] Kang, Y, Wang, F., Ping, S., Effects of Drip Irrigation Frequency on soil Wetting Pattern and Root Distribution of Potato in North China Plain. ASABE Annual Meeting 2002.

[9] Camp, C. R., Sadler, E. J., and Busscher, W. J. A comparison of uniformity measures for drip irrigation systems. Trans. ASAE. Vol. 40. pp. 1013-1020. 1997.

[10] Hanson, B. R., Fipps, G., Martin, E. C. Drip irrigation of row crops: What is the state of the art? www.oznet.k-state.edu/sdi/Abstracts/Drip Irrigation of Row Crops.htm

[11] Weynand, V. L. Evaluation of the application uniformity of subsurface drip distribution systems. M.S. thesis. Texas A\&M University. 2004.

[12] Johnson Hake, S, Hake, K. D, and Kerby, T. A., Planting and Stand Establishment (Chapter 4). Cotton Production Manual, eds. S. Johnson Hake, T. A. Kerby, K. D. Hake, University of California, pp 21-28, 1996.

[13] van Noordwijk, M., Functional Interpretation of Root Length Densities in the Field for Nutrient and Water Uptake. Root Ecology and its Practical Application. Int. Symp. Gumpenstein, A-8952, pp. 207-226. 1982. 